\title{
Cultivation Effects on Quality of Life Indicators: Exploring the Effects of American Television Consumption on Feelings of Relative Deprivation in South Korea and India
}

\author{
Hyeseung Yang, Srividya Ramasubramanian, and \\ Mary Beth Oliver
}

\begin{abstract}
A hypothetical path model investigated how viewing U.S. television would be associated with feelings of relative deprivation among Asians. The South Korean survey data $(N=352)$ revealed that viewing U.S. television was associated with estimates of Americans' affluence, and the estimates were in turn associated with dissatisfaction with Korean society. The Indian survey data $(N=333)$ showed that viewing U.S. television was directly associated with both dissatisfaction with personal life and dissatisfaction with Indian society. The findings suggest that people in both countries may universally experience perceptions of relative deprivation associated with U.S. television consumption.
\end{abstract}

Decades of research have demonstrated that television may affect viewers' perceptions of social reality, with the influence of television on viewers' perceptions thought to be particularly strong when viewers lack direct experience with the content being depicted. That is, when television functions as the primary or exclusive source of information about other people or cultures, it is predicted to have strong influences on shaping and often distorting perceptions.

Publics around the world often learn about the United States from imported media. Unfortunately, however, the "lessons" about the United States may be

Hyeseung Yang (Ph.D., Penn State University) is a full-time instructor in the Department of Mass Communication at Kyungsung University in South Korea. His research interests include social and psychological effects of mass media and new communication technologies.

Srividya Ramasubramanian (Ph.D., Penn State University) is an Assistant Professor in the Department of Communication at Texas A\&M University. Her research interests include media psychology and inter-group communication.

Mary Beth Oliver (Ph.D., University of Wisconsin, Madison) is a Professor in the Department of Film/Video \& Media Studies at Penn State University. Her research interests include media effects, psychology of entertainment, and media and social cognition.

Data collection for this study was supported by a grant from Jimirro Center for Study of Media Influence, College of Communications, Penn State University.

(C) 2008 Broadcast Education Association Journal of Broadcasting \& Electronic Media 52(2), 2008, pp. 247-267 DOI: 10.1080/08838150801992060

ISSN: 0883-8151 print/1550-6878 online 
distorted. Indeed, researchers have argued that among other distortions, U.S. television programs are filled with images and representations that endorse consumerism and are populated by wealthy characters from privileged social classes (e.g., Butsch, 1992; Freeman, 1992; Hirschman, 1988; Lichter, Lichter, \& Rothman, 1994; Thomas \& Callahan, 1982).

Although distortions in media portrayals of wealth may have a variety of effects on viewers' perceptions, this paper focuses on several specific influences that such depictions may have on viewers outside the United States. That is, this paper explores the idea that exposure to U.S. television may cultivate materialistic values as well as perceptions that Americans are more wealthy than may actually be the case. In addition, this paper examines the idea that repeated exposure to the biased representations may culminate in a sense of relative deprivation among them.

The United States is currently the largest exporter of media in the world. The U.S. media industry has continually explored market expansion opportunities in the world, and recently, the focus of this expansion has been Asia (see Sinclair \& Harrison, 2004). Therefore, the overarching objective of this study relates to how viewing of U.S. television programs may be associated with life dissatisfaction among people in Asia. South Korea and India were selected as countries where such effects can be explored, particularly because the two countries enjoy different stages of economic development and because they have different histories of penetration of U.S. media.

\section{Literature Review}

\section{Television Viewing and Cultivation of Capitalist Values}

Cultivation research has primarily focused on the relationship between the social reality portrayed on television and viewers' beliefs in the "television reality." Hawkins and Pingree (1990) noted that there are two different kinds of cultivation effects of television viewing: first-order and second-order social reality beliefs. Firstorder social reality beliefs refer to estimates of frequencies or probabilities of certain concepts or events (e.g., one's belief about the percentage of people who own luxury cars), whereas second-order social reality beliefs involve internalization of certain ideas, attitudes, or values (e.g., one's belief about the importance of material possessions in his or her life). Moreover, Hawkins and Pingree indicated that the two types of social reality beliefs are constructed independently of each other through different cognitive processes, and that "... research should explicitly treat first- and second-order beliefs separately, propose specific theory-based processes for each, and test the effects as directly as possible" (p. 47).

With regard to what Hawkins and Pingree (1990) called second-order cultivation effects, a body of research has explored the idea that U.S. television programming may cultivate capitalist values among international viewers. For example, Tan, Tan, 
and Tan's (1987) study of Philippine high school students found that heavy viewers of U.S. television were more likely to rate "pleasure" as an important value, while they deemphasized "salvation" and "wisdom" (see also Kang \& Morgan, 1988).

Among many capitalist values, materialism may be the most representative. Materialism is often defined as a set of centrally held beliefs about the importance of possessions in one's life (Richins \& Dawson, 1992) or as an attitude orientation emphasizing possessions and money for personal happiness and social progress (Moschis \& Churchill, 1978). However, materialism has received relatively little attention in the context of international cultivation. In other words, little research attention has been paid to the effects of viewing U.S. television on materialism among people outside the United States. Instead, the effects of general or domestic television viewing have usually been explored either within the United States or within other cultures (Allen, 1992; Burroughs, Rindfleisch, \& Shrum, 2002; Cheung \& Chan, 1996; Churchill \& Moschis, 1979; Kang \& Kang, 1998; Shrum, Burroughs, \& Rindfleisch, 2005; Sirgy et al., 1998; Zhang \& Harwood, 2002).

For example, Shrum et al. (2005) found that there was a positive association between television viewing and materialism among their sample of U.S. respondents, and that the association was stronger for those who pay more attention while viewing and for those higher in need for cognition. Similarly, Churchill and Moschis (1979) found that television viewing, along with peer communication about consumption, was positively correlated with materialism among U.S. adolescents. Finally, in a study of Hong Kong high school students, Cheung and Chan (1996) also found positive correlations between the amount of weekday television viewing and the viewer's materialism and trivialization of moral value.

\section{Television Viewing and Cultivation of Estimates of Americans' Affluence}

Heavy exposure to U.S. television programs is predicted not only to affect viewers' value systems (i.e., second-order social reality beliefs), but also to inflate estimates of Americans' affluence (i.e., first-order social reality beliefs). However, this idea has not received extensive research attention in the context of international cultivation. Instead, a body of research has explored the idea within the United States that television viewing in general functions as a magnifying glass by which viewers may amplify their estimates of other people's affluence (Fox \& Philiber, 1978; O'Guinn \& Shrum, 1997; Potter, 1991; Shrum, 2001; Shrum, O'Guinn, Semenik, \& Faber, 1991). For example, O'Guinn and Shrum (1997) found that heavy television viewing was associated with the overestimation of percentage of Americans who were believed to have luxury cars, hot tubs or Jacuzzis, and maids and servants.

In the context of international cultivation, Weimann's (1984) study of Israeli high school and college students found that heavy television viewers were more likely than were light viewers to overestimate the percentage of Americans employed in white collar occupations, the weekly earnings of male workers, and the ownership 
of and spending on material items such as electrical appliances and cars. However, the author did not specifically measure respondents' viewing of U.S. television in the study, making it impossible to conclude that heavy television viewers' overestimation can be associated with U.S. television programs in particular.

\section{Linkage of Cultivation and Relative Deprivation}

Social realities cultivated by viewing U.S. television, whether the realities are first-order or second-order ones, may function as a yardstick by which individuals outside the United States judge the quality of their own lives. The idea that one's subjective well-being is a function of comparative judgments has been well documented (Michalos, 1985; Ross, Eyman, \& Kishchuk, 1986). To be more specific, it is possible to imagine that increased materialism may culminate in feelings of relative deprivation because increased materialism reflects heightened desires for an affluent life. A substantial body of research explored the detrimental effects of materialism on subjective well-being, particularly on satisfaction with personal life, within the United States or within other cultures (Belk, 1984, 1985; Burroughs \& Rindfleisch, 2002; Fournier \& Richins, 1991; Kasser \& Ahuvia, 2002; Kim, Kasser, \& Lee, 2003; Richins \& Dawson, 1992; Ryan \& Dziurawiec, 2001).

In addition to materialism, greater estimation of Americans' affluence may also result in feelings of relative deprivation among viewers outside the United States because such biased estimation may provide frequent moments of comparisons between the quality of their own life and that of better-off American people. However, research on estimation of others' affluence has not been substantially extended to the issue of subjective well-being because the primary purpose of this line of research has typically been to evidence a first-order cultivation effect per se.

\section{Two Aspects of Relative Deprivation}

The term "relative deprivation" was coined by Stouffer, Suchman, DeVinney, Star, and Williams (1949) in their study of American soldiers. The authors pointed out that people tend to compare their rewards with those of others in a comparison group, and that this comparison determines group morale among the troops, suggesting that one's experience of the feeling of relative deprivation may be a corollary of social comparison. One of the most important conceptual distinctions indicated in the relative deprivation literature relates "egoistic" and "fraternalistic" deprivation (Runciman, 1966). Egoistic deprivation refers to feelings of deprivation that develop out of a comparison of one's own situation to the situation of other individuals, whereas fraternalistic deprivation refers to feelings of deprivation that develop out of a comparison of the situation of one's group relative to the situation of another group.

The concepts of egoistic and fraternalistic deprivation seem to explain well how individuals living in economically inferior countries may experience different 
types of relative deprivation as a result of viewing U.S. television. The affluent lives of Americans depicted in media may lead them to claim dissatisfaction with their personal lives, which indicates egoistic deprivation. Additionally, images of Americans may lead them to experience dissatisfaction with their own society because they may perceive their inferior living standard as being caused, at least in part, by systematic problems of their own society, which indicates fraternalistic deprivation.

\section{Experience With the United States}

Cultivation researchers have emphasized that the influence of media information can be attenuated when there is a greater degree of familiarity with the group through other interpersonal sources (Armstrong, Neuendorf, \& Brentar, 1992; Fujioka, 1999). In addition, the contact hypothesis suggests that distorted perceptions of people belonging to other societies might be due to the absence of first-hand interactions with these groups. Therefore, people are predicted to have more accurate perceptions of other groups when they have a larger number of direct sources of information, and particularly when there are numerous meaningful, inter-dependent, friendly interactions (Allport, 1954; Brewer \& Miller, 1988; Hewstone \& Brown, 1986; Pettigrew \& Tropp, 2000).

In this line of reasoning, individuals' direct and indirect experiences with the United States, in addition to television viewing, may have an impact on many beliefs or perceptions explored in this study. For example, it is not difficult to expect that individuals who have experiences of living in or traveling to the United States and who have friends or relatives living in the United States may have different perceptions of the United States in some ways, compared to individuals who do not have such direct and indirect sources of information about the United States.

\section{Viewing Domestic Television}

Although this study is primarily interested in cultivation effects of viewing U.S. television, it is possible to expect that viewing domestic programs, not necessarily viewing U.S. programs, affect values and perceptions explored in this study. Indeed, the themes and format styles for many Indian television programs in domestic channels are heavily drawn from American media, even though they might be localized to suit Indian tastes. For instance, Kaun Banega Crorepati is modeled after Who Wants To Be A Millionaire, the program Movers and Shakers is very similar to David Letterman, India Guide is an imitation of TV Guide, and so on (Cullity, 2002). This phenomenon of imitating American story lines, characters, and even genres in Indian programming has been referred to as "Western recombination." (Crabtree \& Malhotra, 2000). Likewise, a recent study of soap-opera and drama programs on the three major broadcast networks in South Korea revealed that privileged social classes were much more populous on television than in real life (Yang \& Kang, 
2005). Professionals such as doctors and lawyers represented almost $20 \%$ of the all characters, with extremely wealthy industrial families and business executives representing an additional $10 \%$.

\section{Korea Versus India}

Although South Korea and India are both located in Asia, they are different in many respects such as their economic development, languages, religions, culture, prevalence of U.S. media, etc. South Korea is one of the leading industrial countries in Asia, whereas India is a relatively poorer developing country. The World Factbook reports that the average annual household income of India and South Korea in 2005 is U.S.\$3,400 and U.S.\$20,400, respectively (http://www.cia.gov/cia/publications/ factbook). According to the 2001 Indian census, a majority of the Indian population is Hindu (80.5\%) with a small portion of the population being Muslim (13.4\%) and Christian $(2.3 \%)$. In contrast, according to the 2005 Korean census, among people who are religious in South Korea (53.1\% of the population), a majority is Christian $(55.0 \%)$, with the second major religion being Buddhism (43.0\%).

In addition to the aforementioned differences, India and Korea also differ in the penetration of U.S. media. The broadcasting industry in South Korea spent $\$ 790$ million for importing U.S. television programs in 2002, which is $93.4 \%$ of total television program imports. As of 2004 , about $82.9 \%$ of Korean households subscribe to satellite or cable television services that bring in many U.S. programs (refer to the Korean Broadcasting Commission, http://www.kbc.or.kr). However, there are no television channels that broadcast only U.S. programs in South Korea. U.S. programs are usually programmed along with domestic programs in a channel. In contrast, only about $60 \%$ of the total households possess television sets in India, and of the television households, only about $42 \%$ (i.e., of the total households, only about $25 \%$ ) receive cable television services that bring in foreign channels such as CNN, MTV, etc. (refer to the India Brand Equity Foundation, http://www.ibef.org/industry/mediaentertainment.aspx).

\section{Proposed Model}

Based on the review of previous research and theoretical considerations, a hypothetical path model was established to predict the relationship between viewing U.S. television and feelings of relative deprivation in South Korea and India. Figure 1 illustrates the proposed model.

Because U.S. television programs are populated by wealthy characters whose occupations, activities, and possessions are indicative of privileged social classes, viewers may come to overestimate Americans' affluence. Likewise, long-term exposure to images of U.S. television endorsing consumerism may make viewers place materialism in the midst of their value systems. In addition, heavy exposure to U.S. television programs may not only affect affluence estimates and materialism, 
Figure 1

Hypothetical Path Model

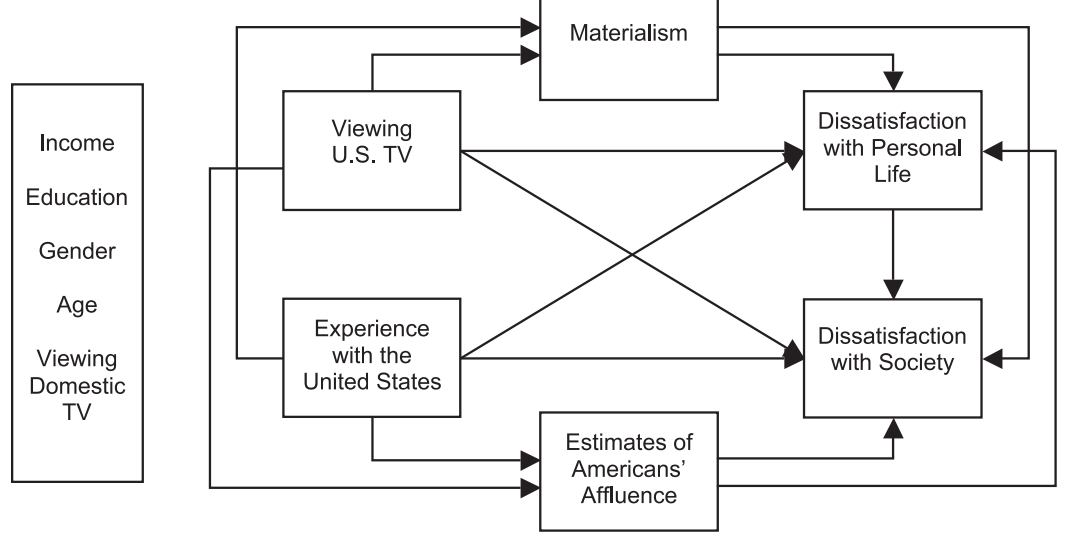

Notes:

1. Viewing domestic TV was assumed to have direct associations with materialism, estimates of Americans' affluence, and two aspects of dissatisfaction, although this figure does not show all the paths for the purpose of simple visualization. The variable was also assumed to have correlations with income and the residual of viewing U.S. television.

2. Demographic variables were also assumed to have direct associations with all of the other six variables. Education was assumed to have correlations with income, gender, and age. Income was assumed to have a correlation with age.

3. A residual correlation was created between viewing U.S. television and experience with the United States.

but also may lead to dissatisfaction with personal life and dissatisfaction with their own society in general, which are indicative of feelings of relative deprivation. This reasoning leads to the following hypotheses:

$\mathrm{H}_{1}$ : Viewing U.S. television will be associated with estimates of Americans' affluence.

$\mathrm{H}_{2}$ : Viewing U.S. television will be associated with materialism.

$\mathrm{H}_{3}$ : Viewing U.S. television will be associated with dissatisfaction with personal life.

$\mathrm{H}_{4}$ : Viewing U.S. television will be associated with dissatisfaction with the society to which one belongs.

In addition to these direct associations, viewing U.S. television and dissatisfaction were assumed to be mediated by affluence estimates and materialism. This reasoning leads to the following hypotheses: 


\section{Journal of Broadcasting \& Electronic Media/June 2008}

$\mathrm{H}_{5}$ : Estimates of Americans' affluence will be associated with dissatisfaction with personal life.

$\mathrm{H}_{6}$ : Estimates of Americans' affluence will be associated with dissatisfaction with the society to which one belongs.

$\mathrm{H}_{7}$ : Materialism will be associated with dissatisfaction with personal life.

$\mathrm{H}_{8}$ : Materialism will be associated with dissatisfaction with the society to which one belongs.

A direct association between dissatisfaction with personal life and dissatisfaction with society was also assumed to examine how one's dissatisfaction with one's own life relates to his or her dissatisfaction with one's own society.

$\mathrm{H}_{9}$ : Dissatisfaction with personal life will be associated with dissatisfaction with the society to which one belongs.

In addition to the nine hypotheses, this study proposes a research question that inquires about the possible differences between the countries (i.e., South Korea and India) with regard to the associations among viewing U.S. television and other beliefs and perceptions.

$\mathrm{RQ}_{1}$ : How is the pattern of the associations among viewing U.S. television and other beliefs and perceptions different between the two countries?

Experience with the United States was included as a variable in the proposed model to examine its influence in relation to the effects of viewing U.S. television because in terms of cultivation research, it is important to examine the effects of media consumption in comparison to the effects of actual, direct experiences. On the basis of this reasoning, another research question was posed.

$\mathrm{RQ}_{2}$ : How is the influence of experience with the United States in relation to that of viewing U.S. television?

Therefore, experience with the United States was also predicted to have direct associations with materialism, estimates of Americans' affluence, and the two aspects of dissatisfaction. Additionally, viewing domestic television and demographic variables such as income, education, gender, and age were included in the model and assumed to have direct associations with materialism, estimates of Americans' affluence, and the two aspects of dissatisfaction. Income level was assumed to be positively correlated with education level and age, and education level was supposed to be negatively correlated with age and gender (i.e., female). 


\section{Methods}

\section{Data Collection}

Surveys were administered in South Korea $(N=352)$ and India $(N=333)$ during January and February 2004. The Korean data were collected in Gwangju City, which has a population of more than 1.35 million people and is the sixth largest city in the country. The Indian data were collected in four cities, Cochin, Chennai, Pune, and Hyderabad, where urban middle class people are prevalent and most of international English channels are accessible. Individuals in public spaces (e.g., shopping centers, parks, etc.) were approached based on a convenience sampling technique. The Korean sample was composed of 167 males and 185 females, with the mean age being $37.47(S D=11.86)$, and the Indian sample was composed of 209 males and 124 females, with the mean age being 33.33 ( $S D=11.96$ ). The Korean sample showed a proper distribution in household income to represent the Korean population, whereas the Indian sample was slightly well-off considering the actual income distribution of Indian urban households. ${ }^{1}$

An English version of the questionnaire was developed by the researchers for Indian respondents, and the questionnaire was translated into the Korean language for Korean respondents. Cultivation research has shown that if television viewing measures are measured prior to other cultivation responses, the magnitude of the cultivation effects may be seriously reduced (Shrum, Wyer, \& O'Guinn, 1998). Therefore, the questionnaire was designed for the order of the measures to be reverse to the causal flow of the variables in the proposed model: the questionnaire presented dissatisfaction variables first and television viewing variables last.

\section{Measures}

Estimates of Americans' Affluence. A modified version of $\mathrm{O}^{\prime}$ Guinn and Shrum's (1997) measure was used to assess respondents' estimates of Americans' possessions and lifestyles associated with affluence. Some items were revised to reflect the change of social circumstances in terms of objects and activities indicative of affluence. Ten items were included in this measure, in which half represented possessions of objects symbolic of affluence (e.g., "I guess _\% of Americans own yachts"), and the other half represented affluent lifestyles (e.g., "I guess __\% of U.S. adults regularly play golf," Cronbach's alphas: .89 for South Korea; 92 for India). The Indian respondents $(M=34.84, S D=19.67)$ reported much higher estimates of Americans' affluence than did the Korean respondents $(M=27.14, S D=14.71)$, $t(683)=5.82, p<.001$.

Materialism. Materialism was measured by Richins and Dawson's (1992) Material Values Scale. This measure is composed of 15 items, including "I admire people who own expensive homes, cars, and clothes," and "The things I own say a lot 
about how well I'm doing in life" (Cronbach's alphas: .79 for South Korea; .77 for India). Materialism was higher among Korean respondents $(M=4.08, S D=.74)$ than among Indian respondents $(M=3.90, S D=.79), t(683)=3.07, p<.01$.

Dissatisfaction With Personal Life. One's dissatisfaction with personal life was measured by the Satisfaction with Life Scale (Meadow, Mentzer, Rahtz, \& Sirgy, 1992). This measure was considered reasonably fit to theoretical assumptions of the current study because it is based on the assumption that life satisfaction is a function of a "comparison." The scale is composed of 10 items, including "Compared to the accomplishments of most people in my position, I am satisfied," and "Compared to what I feel I should have accomplished so far, I am satisfied" (Cronbach's alphas: .91 for South Korea; .89 for India). The Indian respondents reported much higher satisfaction with personal life $(M=4.71, S D=1.01)$ than did the Korean respondents $(M=3.78, S D=1.06), t(683)=11.87, p<.001$.

Dissatisfaction With Society. Dissatisfaction with society is a concept that is rarely measured in social science literatures. Therefore, the researchers developed seven items for the present study asking about one's satisfaction with living in his or her own society, including "If I could live my life over, I would want to live in Korea [India] again," and "I would like to immigrate to another country if circumstances allowed" (Cronbach's alphas: .73 for South Korea; .67 for India). The Indian sample reported much higher satisfaction with society $(M=4.40, S D=.94)$ than did the Korean sample $(M=3.78, S D=.94), t(683)=18.48, p<.001$.

Experience With the United States. Both direct and indirect experience with the United States were measured. One's direct experience was measured by asking (1) if one lived in the United States more than 6 months and (2) how many trips one had made to the United States. In combining these two measures, the experience of living in the country more than 6 months was considered to be equal to 10 trips to the country. One's indirect experience was measured by adding (1) the number of friends and (2) the number of relatives who lived or are living in the United States. Finally, one's experience with the United States was acquired by combining the z-scores for both direct and indirect experience measures.

Viewing U.S. Television. Indian respondents reported their viewing amount for eight television channels that exclusively broadcast programs imported from the United States (Star World, Star Movies, Zee English, Hallmark, AXN, CNN, Fox News, and Discovery Channel). ${ }^{2}$ Subsequently, a total viewing of U.S. television was computed by summing the hours spent watching each of the eight channels. Given that there are no television channels that broadcast only U.S. programs in South Korea, Korean respondents reported their viewing amount for seven types of U.S. programs (televised movies, drama, comedy/sitcom, music/celebrity shows, news, documentary shows, and others). There were considerable gaps between the two samples in weekly viewing of U.S. television. The Indian sample spent more 
time watching U.S. television programs $(M=5.47, S D=6.85)$ than did the Korean sample $(M=1.81, S D=3.23), t(683)=9.04, p<.001$.

Other Variables. The questionnaire included an item asking the amount of time spent watching domestic television programs during a typical week. Korean respondents spent more time watching domestic programs $(M=11.44, S D=13.17)$ than did Indian respondents $(M=5.95, S D=5.93), t(683)=6.97, p<.001$. Demographic variables such as age, gender, education level, and household income were also included in the questionnaire.

\section{Results}

Structural equation modeling application AMOS 5 was used for path analysis of the proposed model, using the maximum likelihood estimation method. Given that the maximum likelihood estimation method assumes multivariate normality (Chou, Bentler, \& Satorra, 1991; West, Finch, \& Curran, 1995), the presence of excessive skewness and kurtosis was univariately checked in the data. Researchers suggest that absolute skewness and kurtosis values greater than 3.0 and 10.0 respectively may indicate a problem (Kline, 1998). Because measures of television viewing (both viewing U.S. television and domestic television) and experience with the United States were positively skewed, a square root transformation was performed for the variables, resulting in a relatively normal distribution of the all variables in the model. $^{3}$

The proposed model fit the whole sample data adequately, $\chi^{2}(7)=12.51(p=$ $.09), \mathrm{GFI}=.994, \mathrm{CFI}=.973, \mathrm{RMSEA}=.047$, given that $\mathrm{GFI}$ and $\mathrm{CFI}$ values above .90 and RMSEA values less than .06 are considered to indicate reasonable or close fit (Hu \& Bentler, 1999). ${ }^{4}$ Reported in the upper part of Table 1 are the estimated path coefficients in the model for the whole sample.

This analysis generally failed to reveal the effects of either viewing U.S. television or experience with the United States on affluence estimates and materialism. Viewing U.S. television was associated only with dissatisfaction with society negatively. Experience with the United States was negatively associated with both dissatisfaction variables. In contrast, viewing domestic television was positively associated with dissatisfaction with society.

Given that the findings of the original model were complex and even contrary to the theoretical reasoning of this study, multiple group path analysis between the Korean and Indian samples was performed for any hidden clues. Two separate twogroup analyses were implemented, first with no constraints and then again with constraints. In the constrained model, the path estimates for each pair of paths in the two groups were imposed to be the same. In multiple group analysis, if the fit of the constrained model is worse than that for the corresponding unconstrained model, then it is concluded that model direct effects differ by group. The multiple group analysis in this study revealed significant differences in model direct effects 
Table 1

Standardized Path Coefficients Estimated

\begin{tabular}{|c|c|c|c|c|c|c|}
\hline & $\begin{array}{l}\text { Viewing } \\
\text { U.S. TV }\end{array}$ & $\begin{array}{l}\text { Experience } \\
\text { With the } \\
\text { United } \\
\text { States }\end{array}$ & $\begin{array}{l}\text { Affluence } \\
\text { Estimates }\end{array}$ & Materialism & $\begin{array}{l}\text { Dissatisfaction } \\
\text { With Personal } \\
\text { Life }\end{array}$ & $\begin{array}{l}\text { Dissatisfaction } \\
\text { With Society }\end{array}$ \\
\hline \multicolumn{7}{|l|}{$\begin{array}{l}\text { Whole sample } \\
\qquad(N=685)\end{array}$} \\
\hline Income & $.10^{* *}$ & $.26^{* * *}$ & $-.20^{* * *}$ & -.05 & .00 & .00 \\
\hline Education & $.10^{* *}$ & $.20^{* * *}$ & $.11^{* *}$ & $-.11^{* *}$ & -.03 & .00 \\
\hline Gender & $-.09 *$ & .06 & $.09 *$ & .02 & $.11^{* *}$ & $.09 * *$ \\
\hline Age & $-.18^{* * *}$ & -.04 & -.04 & -.05 & .01 & -.02 \\
\hline Viewing domestic TV & $(.10)^{* *}$ & no path & -.01 & .03 & .07 & $.11 * *$ \\
\hline Viewing U.S. TV & - & $(.29)^{* * *}$ & .05 & -.01 & -.04 & $-.08^{*}$ \\
\hline $\begin{array}{l}\text { Experience with the } \\
\text { U.S. }\end{array}$ & $(.29)^{* * *}$ & - & -.01 & .05 & $-.09 *$ & $-.10^{* *}$ \\
\hline \multicolumn{7}{|l|}{$\begin{array}{l}\text { Korean sample } \\
\quad(N=352)\end{array}$} \\
\hline Income & -.01 & $.16^{* *}$ & -.01 & -.03 & -.07 & $-.13^{* *}$ \\
\hline Education & .00 & $.17^{* *}$ & -.03 & -.07 & .07 & $.10^{*}$ \\
\hline Gender & -.07 & $.11^{*}$ & .10 & $.15^{* *}$ & .01 & .08 \\
\hline Age & $-.17^{* *}$ & -.02 & .02 & -.01 & .06 & $-.11^{*}$ \\
\hline Viewing domestic TV & $(.15)^{* *}$ & no path & -.10 & -.04 & .04 & .08 \\
\hline Viewing U.S. TV & - & $(.10)^{*}$ & $.13^{*}$ & .03 & -.03 & -.06 \\
\hline $\begin{array}{l}\text { Experience with the } \\
\text { U.S. }\end{array}$ & $(.10)^{*}$ & - & $.12 *$ & $.13^{*}$ & -.04 & -.05 \\
\hline \multicolumn{7}{|l|}{$\begin{array}{l}\text { Indian sample } \\
\qquad(N=333)\end{array}$} \\
\hline Income & $.22^{* * *}$ & $.40^{* * *}$ & $-.27^{* * *}$ & $-.11^{*}$ & -.03 & .02 \\
\hline Education & .02 & .06 & $.12 *$ & -.04 & .04 & .08 \\
\hline Gender & -.05 & .09 & .08 & $-.14^{* *}$ & .10 & .06 \\
\hline Age & $-.15^{* *}$ & .02 & $-.11 *$ & $-.14^{* *}$ & $-.11 *$ & .01 \\
\hline Viewing domestic TV & $(.24)^{* * *}$ & no path & $.20^{* * *}$ & .10 & -.01 & -.06 \\
\hline Viewing U.S. TV & - & $(.27)^{* * *}$ & -.08 & .02 & $.12 *$ & $.11^{*}$ \\
\hline $\begin{array}{l}\text { Experience with the } \\
\text { U.S. }\end{array}$ & $(.27)^{* * *}$ & - & $-.11 *$ & .06 & -.01 & -.01 \\
\hline $\begin{array}{l}\text { Notes: } \\
\text { 1. Gender was coded } \\
\text { 2. Income for the who } \\
\text { samples. } \\
\text { 3. The values in paren } \\
\text { 4. }{ }^{*} p<.05,{ }^{* *} p<.01\end{array}$ & $\begin{array}{l}\text { as males }= \\
\text { le sample }\end{array}$ & $\begin{array}{l}0 \text {; females } \\
\text { was standarc } \\
\text { esent residua }\end{array}$ & $\begin{array}{l}=1 . \\
\text { ized beca } \\
\text { I correlati }\end{array}$ & se of differen & cales betweer & he two country \\
\hline
\end{tabular}

between the Korean and Indian samples, $\chi^{2}$ difference $(54)=191.61, p<.001$. Reported in the lower part of Table 1 are the estimated path coefficients for each sample, and illustrated in Figure 2 is how viewing U.S. television and other variables are related both directly and indirectly as part of the entire path model. ${ }^{5}$

In the Korean sample, viewing U.S. television was positively associated with estimates of Americans' affluence, and in turn the affluence estimates were positively associated with dissatisfaction with society, indicating that viewing U.S. television was indirectly associated with dissatisfaction with society mediated by estimates of Americans' affluence. However, there were no direct associations between viewing U.S. television and dissatisfaction variables. On the other hand, experience with the United States was positively associated with both materialism and affluence 
Figure 2

Estimated Paths From Viewing U.S. TV to Dissatisfaction With Society
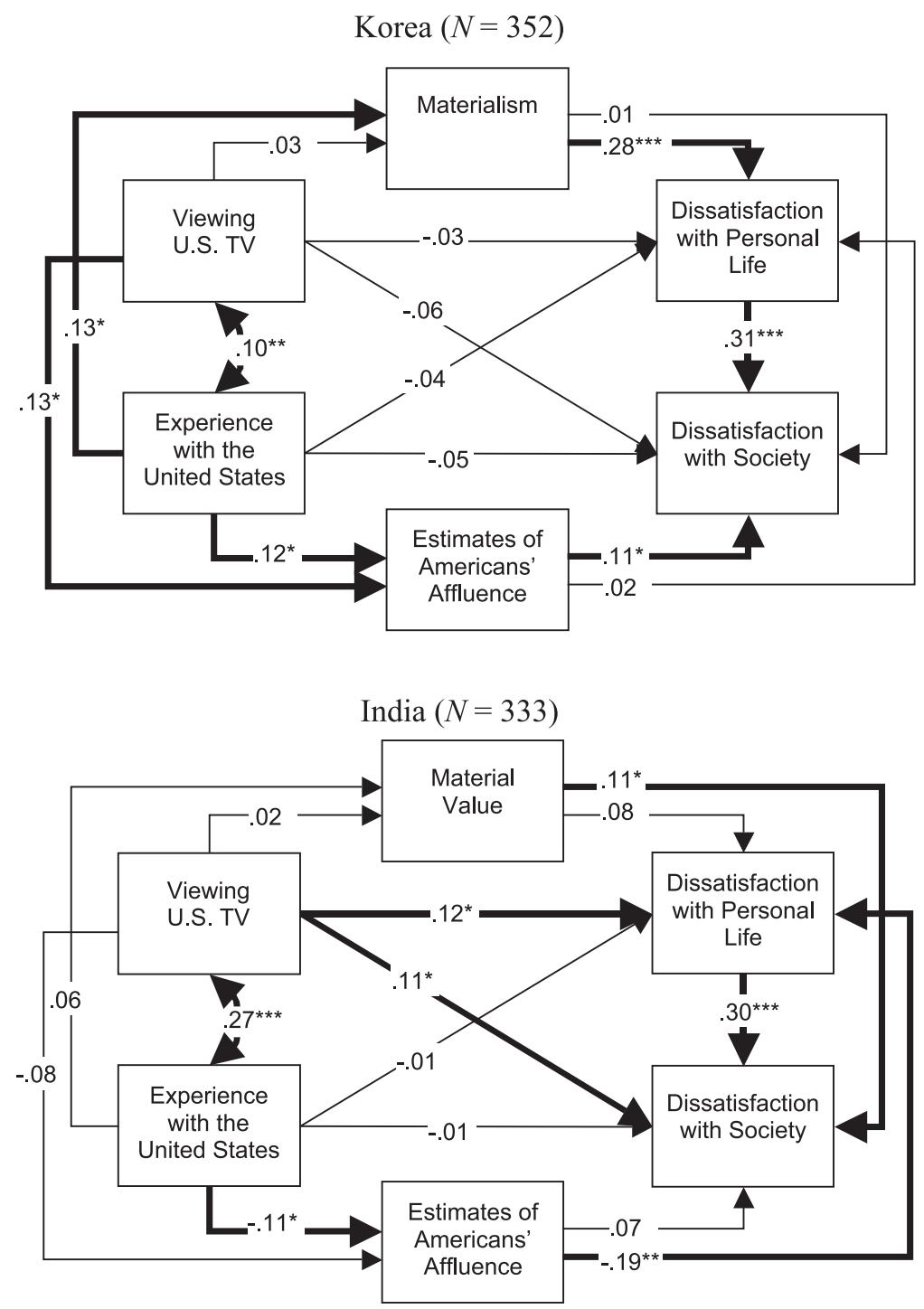

Notes:

1. Path coefficients are standardized.

2. ${ }^{*} p<.05,{ }^{* *} p<.01,{ }^{* * *} p<.001$; two-tailed. 
estimates. Additionally, dissatisfaction with personal life was positively associated with dissatisfaction with society.

In the Indian sample, no mediated associations were found between viewing U.S. television and dissatisfaction variables. Instead, viewing U.S. television was directly and positively associated with both dissatisfaction variables. Interestingly, experience with the United States was negatively associated with estimates of Americans' affluence, and in turn the affluence estimates were negatively associated with dissatisfaction with personal life. Materialism was associated with dissatisfaction with society. Dissatisfaction with personal life was positively associated with dissatisfaction with society as in the Korean sample.

The first research question of this study concerned the differences between the countries with regard to the associations among viewing U.S. television and other beliefs and perceptions. In general, viewing U.S. television was associated with dissatisfaction with society, mediated through estimates of Americans' affluence for the Korean sample, whereas viewing U.S. television was directly associated with both dissatisfaction variables for the Indian sample. For both samples, the paths linking dissatisfaction with personal life to dissatisfaction with society were all statistically significant. Interestingly, estimates of Americans' affluence were found to have a direct association to dissatisfaction with society in the Korean sample, whereas affluence estimates were associated with dissatisfaction with personal life in the Indian sample. On the contrary, materialism had a direct association to dissatisfaction with personal life in the Korean sample, whereas materialism was associated with dissatisfaction with society in the Indian sample.

The second research question of this study concerned the effects of actual, direct experiences with the United States in comparison to the influence of viewing U.S. television. Experience with the United States, compared with viewing U.S. television, was found to have different associations with other variables. It was notable that in the Korean sample, experience with the United States was associated with both materialism and affluence estimates, whereas viewing U.S. television was associated with only materialism. It was also worth noting that in the Indian sample, experience with the United States was associated only with affluence estimates negatively, whereas viewing U.S. television was not associated with either the estimates or materialism.

In terms of hypothesis testing, Hypothesis 1 concerning the association between viewing U.S. television and estimates of Americans' affluence received support for the Korean sample but did not receive support for the Indian sample. Hypothesis 2 concerning the association between viewing U.S. television and materialism did not receive support for either the Korean or the Indian samples. Hypothesis 3 and Hypothesis 4 concerning the association between viewing U.S. television and dissatisfaction variables received support for the Indian sample but did not receive support for the Korean sample. Hypothesis 5 concerning the association between estimates of Americans' affluence and dissatisfaction with personal life received statistical support only for the Indian sample, with the direction being negative. 
Hypothesis 6 concerning the association between estimates of Americans' affluence and dissatisfaction with society received support only for the Korean sample. Hypothesis 7 concerning the association between materialism and dissatisfaction with personal life received support only for the Korean sample, but Hypothesis 8 concerning the association between materialism and dissatisfaction with society received support only for the Indian sample. Finally, Hypothesis 9 concerning the association between the two dissatisfaction variables received support for both samples.

\section{Discussion}

This study examined the possible effects of U.S. television consumption on feelings of relative deprivation among Asian viewers, contending that the issue may be well explored by combined perspectives of first- and second-order cultivation effects and the concepts of egoistic and fraternalistic deprivation. The Indian data revealed that heavy exposure to U.S. television may be directly associated with dissatisfaction with own life and Indian society. On the other hand, the Korean data revealed that heavy exposure to U.S. television may be related to higher estimates of Americans' affluence, and those affluence estimates, in turn, may be associated with dissatisfaction with Korean society.

In spite of different paths revealed between the two samples, the findings of this study suggest that people in both countries may universally experience perceptions of fraternalistic deprivation (i.e., dissatisfaction with their own societies) due to U.S. television consumption. This finding may have political implications and concerns about globalization of mass media. As Weimann (1984) pointed out in the study of the impact of American television in Israel, "'selling of the U.S.' by portraying a false, over-idealized reality through the dissemination of mass-media fictional images" (p. 195) should be reconsidered because repeated exposure to the biased images may influence international viewers' value system, reality judgments, and perceptions of relative deprivation.

The different path patterns between the two countries are definitely worth further speculation. One of the reasons may relate to the fact that the total viewing of U.S. television for the Korean sample is considerably smaller than that of the Indian sample. Another reason may be derived from the different cultural backgrounds of the two countries. South Korea is one of the most Westernized countries in Asia, and it has a long history of the prevalence of U.S. media. In contrast, India has just opened doors to Western media and consumer goods. The direct associations between heavy exposure to U.S. television and dissatisfaction measures in the Indian sample might reflect the impact of new consumer culture introduced by U.S. television programs.

Additionally, the negative associations between experience with the United States and estimates of Americans' affluence and between the affluence estimates and 


\section{Journal of Broadcasting \& Electronic Media/June 2008}

dissatisfaction for the Indian sample may be understood in two different ways. The first interpretation may relate a function of positive psychological outcomes of upward social comparisons. Research has shown that individuals could draw inspiration or optimistic expectations from better-off others when their standing on the comparison dimension is changeable and controllable (Buunk, Collins, Taylor, \& Van Yperen, 1990; Lockwood \& Kunda, 1997; Major, Testa, \& Bylsma, 1991). This reasoning seems to be supported in part by the much higher scores of satisfaction with personal life and society scores among the Indian samples. Although statistical data indicate that India's economic power is much inferior to that of South Korea, India recently has enjoyed rapid economic growth. Furthermore, the Indian data were collected from the area where urban middle class people are prevalent and international English channels are accessible. The nature of the Indian sample may account for the results in some ways in case they feel that their standard of living is much higher than that of other social members in India.

Another interpretation may be that the Indian respondents' experiences with the United States may actually relate to lower social class individuals in the United States. That is, the friends and relatives of the respondents may have an inferior standard of living in the United States, leading the respondents to make poor estimates of Americans' affluence in general.

This study generally failed to find the mediated role of materialism between the consumption of U.S. television and life dissatisfaction. Although some associations were found between materialism and dissatisfaction variables, a direct association between viewing U.S. television and materialism was not found in both samples. Materialism seems to be affected mostly by other sources irrelevant to U.S. television, including demographic variables and other societal factors (i.e., living with affluent neighbors, etc.). In terms of cultivation theory, the findings of this study suggest that the first-order cultivation effect (i.e., affluence estimation), instead of the second-order cultivation effect (i.e., materialism), may well explain the association between U.S. television consumption and feelings of relative deprivation at least among South Koreans.

In addition to the implications and issues above, it is important to acknowledge the limitations associated with the present study that suggest additional avenues for future work in this area. First, findings of this study should be carefully interpreted with regard to the direction of causality. Although viewing U.S. television was assumed as a variable that may affect individual materialism, reality judgments, and life dissatisfaction, people who have material values and distorted views of Americans' affluence may be more attracted to U.S. television programs. By compiling research from many different countries, Kasser (2002) indeed points out that materialistic people are perhaps more likely to expose themselves to television. In particular, the association between viewing U.S. television and dissatisfaction for the Indian sample suffers from a reverse causal explanation. In other words, people who are dissatisfied with their life, due to many reasons such as unemployment or lack of money to find sources of amusement other than television, may watch more television. 
Second, the Indian data show that heavy exposure to domestic television programs, instead of heavy exposure to U.S. television programs, is strongly related to higher estimates of Americans' affluence. Future research may want to address this issue more thoroughly by exploring the nature of the domestic television content that may contribute to this effect.

Third, the respondents were selected based on a convenience sampling method. Employing nationwide probability samples could be the best way to capture a more generalizable picture of the influence of the consumption of U.S. television in the countries.

Finally, different methods were applied to measure viewing U.S. television in the two countries (i.e., channels vs. program types). Future research may want to develop a more uniform measure applicable to multi-country samples. In addition, although this study proposed the effects of general viewing of U.S. television, there are some alternatives to this measure. Because news and documentary programs must be different from drama and soap operas in representing Americans' lifestyles and possessions, viewing of specific genres may be employed to inspect this issue (Carlson, 1993; O'Guinn \& Shrum, 1997). The proportion of U.S. programs watched among one's total viewing of television may also be an alternative.

In spite of all the limitations, however, experiences of fraternalistic deprivation due to "mainstream" television consumption by people living in "marginal" soci-

eties on the globe may open a new, insightful domain of research in the international communications area.

\section{Appendix: Created or Modified Measures by the Researchers}

\section{Estimates of Americans' Affluence}
1. I guess $\%$ of U.S households have swimming pools.
2. I guess $\_$_ $\%$ of U.S people own luxury cars.
3. I guess $\%$ of U.S people own horses.
4. I guess $\%$ of U.S people own yachts.
5. I guess $\%$ of U.S people own second or vacation homes.
6. I guess $\quad \%$ of U.S people go on a vacation more than once a year.
7. I guess _ $\%$ of U.S people regularly attend opera shows.
8. I guess $\quad \%$ of U.S adults regularly have wine with dinner.
9. I guess $\%$ of U.S adult women regularly get a manicure.
10. I guess _ $\%$ of U.S adults regularly play golf.

\section{Satisfaction With Society}

1. I am satisfied with the economic environment of Korea (India). 


\section{Journal of Broadcasting \& Electronic Media/June 2008}

2. I am satisfied with the social/political environment of Korea (India).

3. Wealth is fairly distributed in Korea (India).

4. I am proud of being a Korean (an Indian).

5. If I could live my life over, I would want to live in Korea (India) again.

6. I would like to immigrate to another country if circumstances allowed.

7. I am satisfied with this country in general.

\section{Notes}

${ }^{1}$ The annual household income of the Korean sample showed a reasonable distribution (i.e., less than U.S. $\$ 15,000,22.7 \%$; U.S. $\$ 15,000-30,000,52.0 \%$; more than U.S. $\$ 30,000$, $25.3 \%$ ), given that the average annual household income in South Korea as of 2005 was about U.S.\$20,400 (http://www.cia.gov/cia/publications/factbook). However, the distribution of annual household income for the Indian sample was somewhat negatively skewed (i.e., less than U.S.\$1,300, $18.9 \%$; U.S.\$1,301-2,600, $15.3 \%$; U.S.\$2,600-4,000, $15.3 \%$; more than U.S. $\$ 4,000,50.5 \%)$, compared to the actual income distribution of urban households in India (i.e., less than U.S.\$1,000, 14.3\%; U.S.\$1,001-2,000, 31.7\%; more than U.S.\$2,000, 54\%; (National Council of Applied Economic Research, http://www.ncaer.org).

${ }^{2}$ Both program-type measure and channel measure were employed in the questionnaire for the Indian sample, and there was a strong correlation between these two measures $(r=$ $.67, p<.001)$. However, the channel measure was used in subsequent data analyses because it had greater face validity and was less kurtotic and positively skewed.

${ }^{3}$ Experience with the United States was measured by both direct and indirect experiences. Each measure was square rooted respectively first and then the $z$-scores for each measure were combined.

${ }^{4}$ The model estimated a residual correlation between viewing U.S. television and viewing domestic television. The proportions of unexplained variance (disturbance, $1-R^{2}$ ) for each endogenous variable were as follow: Viewing U.S. TV $=.93(.96, .93)$; Experience with the U.S. $=.88(.93, .82) ;$ Estimates of Americans' Affluence $=.94(.95, .79) ;$ Materialism $=.98$ $(.95, .93)$; Dissatisfaction with Personal Life $=.89(.91, .92)$; and Dissatisfaction with Society $=$ $.72(.82, .86)$. The values in the parentheses represent the disturbances from the subsequent analyses of the Korean and Indian samples, respectively.

${ }^{5}$ Although this study focuses on the effects of viewing U.S. television in general, some may argue that exploring the effects of viewing U.S. entertainment programs, rather than the total viewing of U.S. television programs, is appropriate to the issue of this study particularly because entertainment programs tend to depict images of materially comfortable lifestyles. Therefore, in addition to the original model, another model was analyzed, where viewing U.S. television was replaced with viewing U.S. entertainment programs. The time spent watching entertainment channels (i.e., Star World, Star Movies, Zee English, Hallmark Channel, and AXN) and entertainment genres (U.S. televised movies, U.S. drama, U.S. comedy/sitcom, and U.S. music/celebrity shows) was calculated for the Indian and Korean samples, respectively. This new model fit the whole sample data adequately, $\chi^{2}(7)=9.53(p=.22)$, GFI = $.997, \mathrm{CFI}=.996, \mathrm{RMSEA}=.023$. However, the model did not produce any notable results, compared with the original model. Although the multiple group path analysis of this new model revealed significant differences in path pattern between the two samples, $\chi^{2}$ difference $(40)=$ $162.09, p<.001$, the significance and direction of paths were almost identical with those of the previous multiple group path analysis. Only three paths that were previously significant in the original model were found insignificant or marginally significant due to reduced amount of viewing: viewing U.S. entertainment programs $\rightarrow$ estimates of Americans' affluence $(p=$ $.08)$ in the Korean sample; viewing U.S. entertainment programs $\rightarrow$ dissatisfaction with society $(p=.17)$, and experience with the United States $\rightarrow$ estimates of Americans' affluence $(p=$ $.07)$ in the Indian sample. 


\section{References}

Allen, R. L. (1992). Communication processes and consumerism: The case of Venezuela. Howard Journal of Communication, 4, 50-74.

Allport, G. W. (1954). The nature of prejudice. Oxford, England: Addison-Wesley.

Armstrong, G. B., Neuendorf, K. A., \& Brentar, J. E. (1992). TV entertainment, news, and racial perceptions of college students. Journal of Communication, 42, 153-176.

Belk, R. W. (1984). Three scales to measure constructs related to materialism: Reliability, validity, and relationships to measure of happiness. In T. Kinnear (Ed.), Advances in consumer research (pp. 291-297). Provo, UT: Association for Consumer Research.

Belk, R. W. (1985). Materialism: Trait aspect of living in the material world. Journal of Consumer Research, 12, 265-279.

Brewer, M. B., \& Miller, N. (1988). Contact and cooperation: When do they work? In P. A. Katz \& D. A. Taylor (Eds.), Eliminating racism: Profiles in controversy (pp. 315-326). New York: Plenum Press.

Burroughs, J. E., \& Rindfleisch, A. (2002). Materialism and well-being: A conflicting values perspective. Journal of Consumer Research, 29, 348-370.

Burroughs, J. E., Rindfleisch, A., \& Shrum, L. J. (2002). Does television viewing promote materialism? Cultivating American perceptions of the good life. Advances in Consumer Research, 29, 442-443.

Butsch, R. (1992). Class and gender in four decades of television situation comedies. Critical Studies in Mass Communication, 9, 387-399.

Buunk, B., Collins, R., Taylor, S. E., \& Van Yperen, N. (1990). The affective consequences of social comparison: Either direction had its ups and downs. Journal of Personality and Social Psychology, 59, 1238-1249.

Carlson, J. M. (1993). Television viewing: Cultivating perceptions of affluence and support for capitalist values. Political Communication, 10, 243-257.

Cheung, C., \& Chan, C. (1996). Television viewing and mean world value in Hong Kong's adolescents. Social Behavior and Personality, 24, 351-364.

Chou, C. P., Bentler, P. M., \& Satorra, A. (1991). Scales test statistics and robust standard errors for non-normal data in covariance structure analysis: A Monte Carlo study. British Journal of Mathematical and Statistical Psychology, 44, 347-357.

Churchill, G. A., \& Moschis, G. P. (1979). Television and interpersonal influences on adolescent consumer learning. Journal of Consumer Research, 6, 23-35.

Crabtree, R. D., \& Malhotra, S. (2000). A case study of commercial television in India: Assessing the organizational. Journal of Broadcasting \& Electronic Media, 44, 364-385.

Cullity, J. (2002). The global desi: Cultural nationalism on MTV India. Journal of Communication Inquiry, 26, 408-425.

Fournier, S., \& Richins, M. L. (1991). Some theoretical and popular notions concerning materialism. Journal of Social Behavior and Personality, 6, 403-414.

Fox, W. S., \& Philliber, W. W. (1978). Television viewing and the perception of affluence. Sociological Quarterly, 19, 103-112.

Freeman, L. (1992). Social mobility in television comedies. Critical Studies in Mass Communication, 9, 400-406.

Fujioka, Y. (1999). Television portrayals and African American stereotypes: Examination of television effects when direct contact is lacking. Journalism \& Mass Communication Quarterly, 76, 52-75.

Hawkins, R. P., \& Pingree, S. (1990). Divergent psychological processes in constructing social reality from mass media content. In N. Signorielli \& M. Morgan (Eds.), Cultivation analysis: New directions in media effects research (pp. 35-50). Newbury Park, CA: Sage.

Hewstone, M., \& Brown, R. (1986). Contact is not enough: An intergroup perspective on the "contact hypothesis." In M. Hewstone \& R. Brown (Eds.), Contact and conflict in intergroup encounters: Social psychology and society (pp. 1-44). Cambridge, MA: Basil Blackwell. 


\section{Journal of Broadcasting \& Electronic Media/June 2008}

Hirschman, E. C. (1988). The ideology of consumption: A structural-syntactical analysis of "Dallas" and "Dynasty." Journal of Consumer Research, 15, 344-359.

Hu, L., \& Bentler, P. M. (1999). Cutoff criteria for fit indexes in covariance structure analysis: Conventional criteria versus new alternatives. Structural Equation Modeling, 6, 1-55.

Kang, J. G., \& Kang, S. (1998). Television's influence on cultural and societal values among Japanese students. Journal of Asian Pacific Communication, 8, 181-190.

Kang, J. G., \& Morgan, M. (1988). Culture clash: U.S. television programs in Korea. Journalism Quarterly, 65, 431-438.

Kasser, T. (2002). The high price of materialism. Cambridge, MA: The MIT Press.

Kasser, T., \& Ahuvia, A. C. (2002). Materialistic values and well-being in business students. European Journal of Social Psychology, 32, 137-146.

Kim, Y., Kasser, T., \& Lee, H. (2003). Self-concept, aspiration, and well-being in Korea and the United States. Journal of Social Psychology, 143, 277-290.

Kline, R. B. (1998). Principle and practice of structural equation modeling. New York: The Guilford Press.

Lichter, S. R., Lichter, L. S., \& Rothman, S. (1994). Prime time: How TV portrays American culture. Washington, DC: Regnery.

Lockwood, P., \& Kunda, Z. (1997). Superstars and me: Predicting the impact of role models on the self. Journal of Personality and Social Psychology, 73, 91-103.

Major, B., Testa, M., \& Bylsma, W. (1991). Responses to upward and downward social comparisons: The impact of esteem-relevance and perceived control. In J. Suls \& T. A. Wills (Eds.), Social comparison: Contemporary theory and research (pp. 237-260). Hillsdale, NJ: Lawrence Erlbaum Associates, Inc.

Meadow, H. L., Mentzer, J. T., Rahtz, D. R., \& Sirgy, M. J. (1992). A life satisfaction measure based on judgment theory. Social Indicators Research, 26, 23-59.

Michalos, A. C. (1985). Multiple discrepancies theory (MDT). Social Indicators Research, 16, 347-414.

Moschis, G. P., \& Churchill, G. A. J. (1978). Consumer socialization: A theoretical and empirical analysis. Journal of Marketing Research, 15, 599-609.

O'Guinn, T. C., \& Shrum, L. J. (1997). The role of television in the construction of consumer reality. Journal of Consumer Research, 23, 278-294.

Pettigrew, T. F., \& Tropp, L. R. (2000). Does intergroup contact reduce prejudice: Recent metaanalytic findings. In S. Oskamp (Ed.), Reducing prejudice and discrimination. "The Claremont Symposium on Applied Social Psychology" (pp. 93-114). Mahwah, NJ: Lawrence Erlbaum Associates, Inc.

Potter, W. J. (1991). Examining cultivation from a psychological perspective. Communication Research, 18, 92-113.

Richins, M. L., \& Dawson, S. (1992). A consumer values orientation for materialism and its measurement: Scale development and validation. Journal of Consumer Research, 19, 303316.

Ross, M., Eyman, A., \& Kishchuk, N. (1986). Determinants of subjective well-being. In J. M. Olson, C. P. Herman, \& M. P. Zanna (Eds.), Relative deprivation and social comparison: The Ontario symposium (Vol. 4, pp. 79-93). Hillsdale, NJ: Lawrence Erlbaum Associates, Inc.

Runciman, W. G. (1966). Relative deprivation and social justice: A study of attitudes to social inequality in twentieth-century England. Berkeley: University of California Press.

Ryan, L., \& Dziurawiec, S. (2001). Materialism and its relationship to life satisfaction. Social Indicators Research, 55, 185-197.

Shrum, L. J. (2001). Processing strategy moderates the cultivation effect. Human Communication Research, 27, 94-120.

Shrum, L. J., Burroughs, J. E., \& Rindfleisch, A. (2005), Television's cultivation of material values. Journal of Consumer Research, 32, 473-470.

Shrum, L. J., O'Guinn, T. C., Semenik, R. J., \& Faber, R. J. (1991). Processes and effects in the construction of normative consumer beliefs: The role of television. In R. H. Holman \& 
M. R. Solomon (Eds.), Advances in consumer research (Vol. 18, pp. 755-763). Provo, UT: Association for Consumer Research.

Shrum, L. J., Wyer, R. S., \& O'Guinn, T. C. (1998). The effects of television consumption on social perceptions: The use of priming procedures to investigate psychological processes. Journal of Consumer Research, 24, 447-458.

Sinclair, J., \& Harrison, M. (2004). Globalization, nation, and television in Asia: The cases of India and China. Television \& New Media, 5, 41-54.

Sirgy, J. M., Jin-Lee, D., Kosenko, R., Meadow, H. L., Rahtz, D., Cicic, M. et al. (1998). Does television viewership play a role in the perception of quality of life? Journal of Advertising, 27, 125-142.

Stouffer, S. A., Suchman, E. A., DeVinney, L. C., Star, S. A., \& Williams, R. M. (1949). The American soldier: Adjustment during army life (Vol. 1). Princeton, NJ: Princeton University Press.

Tan, A. S., Tan, G. K., \& Tan, A. S. (1987). American television in the Philippines: A test of cultural impact. Journalism Quarterly, 63, 537-541.

Thomas, S., \& Callahan, B. (1982). Allocating Happiness: TV families and social class. Journal of Communication, 32, 184-190.

Weimann, G. (1984). Images of life in America: The impact of American TV in Israel. International Journal of Intercultural Relations, 8, 185-197.

West, S. G., Finch, J. F., \& Curran, P. J. (1995). Structural equation modeling with nonnormal variables: Problems and remedies. In R. H. Hoyle (Ed.), Structural equation modeling: Concepts, issues, and applications (pp. 56-75). Thousand Oaks, CA: Sage.

Yang, M. H., \& Kang, H. C. (2005). The portrayal of female managers and CEO in the television drama. Korean Journal of Communication Research, 49(5), 95-123.

Zhang, Y. B., \& Harwood, J. (2002). Television viewing and perceptions of traditional Chinese values among Chinese college students. Journal of Broadcasting \& Electronic Media, 46, 245-264. 
Copyright of Journal of Broadcasting \& Electronic Media is the property of Broadcast Education Association and its content may not be copied or emailed to multiple sites or posted to a listserv without the copyright holder's express written permission. However, users may print, download, or email articles for individual use. 